\title{
Kennan and the Neglected Variable in Post-Socialist Societies: The Loss of Honest Dialogue and the Need for Empathy
}

\section{Jesenko Tešan}

Department of Sociology, University College Cork, Ireland

e-mail: jesenko.tesan@cantab.net

Joan Davison

Department of Political Science, Rollins College, Winter Park, FL, USA

e-mail:jdavison@rollins.edu

\section{Abstract:}

This paper analyzes the symbolism of George Kennan's famous " $X$ " article relative to the challenges of contemporary post-socialist and post-conflict transitions. It unpacks recent developments in the field of contemporary political discourse, discussing the critical application of practices such as thinking with your heart, parrhesis, and pathos, as well as Kennan's suggestion of the significance of uncertainty and reflection for global relations. The central question is: What would Kennan write in an $\mathrm{X}$ Article to the societies and states in transition? While various definitions of the term "parrhesis" exist, this paper employs both the definition suggested by Michel Foucault who understood it as "fearless speech" and Eric Voegelin who closely follows Plato's meaning linking it with "heart", i.e. vision of the spiritual, an existential (dis)order of representatives of a society.

Keywords: conflict, parrhesis, communication, liminality, transitions.

\section{The Significance of Uncertainty}

In mathematics, $\mathrm{X}$ often symbolizes an unknown variable which can be discrete or continuous. In the famous X Article the letter replaced the signature of the author, George Kennan, Deputy Chief of the US Mission in Moscow in 1946. Kennan, as a Foreign Service member, necessarily used a pseudonym in the Foreign Affairs publication, but we contend that Kennan's relative anonymity and 
use of the variable also symbolizes his personal experience and his political theoretical perspective $[30]$.

Kennan's mother died shortly after his birth, and he felt himself orphaned. He pondered his identity as he moved to his grandmother's home in Germany and later attended military boarding school. In this context, the X identifier was a variable - who was he? What should he call himself? For Kennan then, the $\mathrm{X}$ might be considered more than a pseudonym for anonymity. The $\mathrm{X}$ also represented his contemplation of self and the human condition. A name would create certainty and limit his identity; the $\mathrm{X}$ allowed for openness, searching, pathos, and uncertainty.

Indeed this sense of disquieted uncertainty also characterized Kennan's response to America's policies following the publication of the X article. Kennan contended that policy-makers misinterpreted and misapplied his assessment of Soviet character and advice for the United States. Specifically, Kennan asserted that he did not intend containment to be only a policy toward the USSR. Rather, containment also needed to contemplate and consider the US's own limits and needs, and from this perspective develop a policy which positioned the US for moral leadership. Indeed, such advice was consistent with Kennan's standards for his personal character and behaviour.

Stefan Rossbach writes convincingly about the spiritual Kennan and his valuation of parrhesis against modern gnosticism, [39] consistent with Michel Foucault's genealogy of the subject [12], [13]. Rossbach claims that Kennan did not intend the $\mathrm{X}$ article as a call for the US to engage the USSR in a Cold War. Kennan did perceive the USSR as embracing its gnosis, its zealous truth about people and systems, but Kennan opposed a US military effort to counter the Soviet particular truth [39]. Instead, Kennan's preference was for a parrhesis in which the US continuously contemplated and meditated in a form of self-criticism which would enable the country to strive to be its best self, i.e., a civilizing model of leadership in the world consistent with Norbert Elias understanding [35], [36]. The Marshall Plan would constitute such leadership. So too, would an attentiveness to domestic weaknesses, such as racial inequality. Practices such as McCarthyism, in which US leaders in Congress asserted a single gnostic truth without serious selfreflection, were contrary to Kennan's advice. Further, Kennan opposed the mimetic violence associated with contending truths and "fighting" the Cold War [2], [3], [16], [17], [18]. Rather he reasoned the US should focus upon enhancing the well-being of Americans and through example and assistance, other peoples and countries.

The decline of America's leadership beginning after the Vietnam War witnesses to the error of dismissing Kennan's preference for self-reflection and moral leadership. The US's messianic gnostic anti-communist crusade led to eternal divisions and unattended social problems. Further this behaviour now continues in the post-9/11 period with the United States' national security machinery again launching messianic crusades in distant lands and in some cases against "unrealities." Rossbach notes that Kennan identified crisis in "The inability to distinguish reality from unreality" [39, p. 215]. He discusses that in 1988 Kennan wrote that such a condition would cause the US to "lose both the credibility of true moral behaviour and the great force such behaviour is admittedly capable of exerting" [39, p. 215]. Kennan's prognosis seems correct.

Indeed in the current era, Kennan's spiritual reflections still offer valuable thoughts for leaders and states willing to contemplate how to become their own best self. The post-Cold War proliferation of complex wars involving claims of religious and ethnic truths provides abundant context for consideration of what is civilizing. Yet, contrary to parrhesis' emphasis on such contemplation of the truth, these conflicts have seized the Gnostics' hubristic claim of the truth, and fuel cyclical violence. The inability or unwillingness to distinguish unreality from reality contributes to decay and death, and in countries such as Syria the destruction of great and historic symbols of civilization [20, pp. $131-146]$, [2]. The intentionality with which civilization and its accomplishments and symbols are destroyed highlights a crusading messianism and spiritual deconstruction which Kennan probably would lament, likely concurring with Hennigsen's argument. Kennan, a diplomat, would advise attention to self-reflection, pathos, and discourse. As a 
former ambassador to both the Soviet Union and Yugoslavia, Kennan's advice might hold special insight for post-socialist societies in transition struggling with contending truths and unrealities.

\section{The Origin of Parrhesis}

Philosophy starts from the basic question: what is cosmos and what is being? Yet, often the fact is ignored that these question(s) appear not in an empty sphere, a sphere where no one dwells. These questions surface among humans in their conversations. Accordingly, we define conversation as a historical fact, and thus as part of the most fundamental phenomenon of society which is discourse. Thence history appears at the moment when humans (subjects) start to converse either through art as in cave paintings or speech forms such as Greek tragedy and later novels [1]. Agnes Horvath identifies Palaeolithic cave paintings as the representation of artistic form as discourse. One of the most strikingly beautiful examples of this human communication is the collection of murals in Altamira, Spain. As Horvath would argue, these paintings are the symbolic forms of a particular epoch which place prehistoric humans within the full experience of nature:

... The caves of Altamira, Chauvet, Cosquer, Lascaux, Le Le Madeleine and others were all hermetically sealed tubes, often miles long, containing the concentrated scenes of a life in delight and strength, with hundreds of paintings expressed - close to saturation point - the representation of the fairest and the best of life [28, p. 26].

Indeed, we translate this phenomenon, even in contemporary art, as a form of "muted" or " $\mathrm{X}$ " storytelling phenomenon ala Kennan. The author's anonymity opens the message to various interpretations.

Sliding across epochs one arrives at Homer and his "singing" or journey storytelling, an approach which sparks contemplation prior to responsive conversation. In Homer's Odyssey [22, book 1-12] it is not just the story that is being told. The very journey Homer relates intends to knit us into the action of opening the heart, thereby inviting us to life and constant movement. In Plato's sense, this movement is kinesis, the most fundamental action which presents the divine to mortal, i.e. human. Once this stirring movement, only seemingly telegraphic, fragmented, and "out-ofcontext", gains momentum it becomes a form of speech, thus history and reality. In one space and time, starting with one voice and tone, this action slides through space, regardless of cultural milieu, binding different tones and voices in what is called conversation or parrhesis.

In ancient Greece this type of conversation or parrhesis evolved into the typical Hellenic tragedy and later into Plato's philosophy. This form of actualisation of history became the main pillar of the Greek polis and hence democracy. Yet this ancient development in conversation now troubles us as it did Foucault. Why are some human hearts, such as Kennan's, open and attentive, while other hearts grow cirrhotic or rigid? What pathology arrests such human hearts? Is there a relation between parrhesis and democracy? Can the core of Hellenic democracy reveal an antidote for uncivilized politics, messianic crusades, and economic and ethnoreligious empires, whether local or global? Might such conversation especially benefit societies in transition in which individuals must come to understand one another anew and apart from categories of socialism? And what of the liminality following ethnic conflicts in which communities struggle to transition from enemy to co-citizen? In Szakolczai's words regarding the opening of the heart:

... I suggest a turn away from 'reason', a guide considered already by Max Weber as unreliable even for ordinary liminal situations, and look into something which for us seems the exact opposite of reason and as a most unreliable guide, which is the heart $[45$, p. 5].

In today's world, particularly in post-socialist, post-conflict societies multiple truths buzz amidst contending claims of ultimate truth and knowledge. The restoration of the practice of parrhesis and conversation is daunting, but offers a foundation for the reflective deliberation of civilizing politics. 
We define parrhesis as not merely truth telling, or "fearless speech", but rather a primal motion towards an opening of the human heart. Parrhesis is similar to Michel Foucault's arguments in the lectures at the Collège de France (1981 - 1984), and represents an ongoing phenomenon. It is the phenomenon of the most fundamental action, which springs from the level of the human heart. Foucault points at his presentation of truth, thus parrhesis, in the following:

...My intention was not to deal with the problem of truth, but with the problem of the truthteller, or of truth-telling as an activity: ... who is able to tell the truth, about what, with what consequences, and with what relations to power .... [W]ith the question of the importance of telling the truth, knowing who is able to tell the truth, and knowing why we should tell the truth, we have the roots of what we could call the 'critical' tradition in the West [14].

Such a tradition might benefit polarized societies seeking to transition or rebuild.

Parrhesis in our Foucauldian terms is asymmetric activity. Foucault emphasizes the polarity between the passive seeker and active teller of truth. Truth belongs to no one, but emerges via parrhesis. From the perspective of Gorbachev, we might view parrhesis as glasnost, a type of openness to the true opinions which might be hurtful or challenging. Thus, this initial action of opening your heart is risky because this truth telling (and listening) is potentially defiant and even dangerous. The gravity becomes especially keen when critical decisions a wait, such as when leaders operating in the realm of power politics consider truths which affect not only themselves but peoples or nations. Parrhesis often counters empires of truths, laws, identities, and lands [14], [40, p. 33, note 4: "four major figures of truth-telling, the prophet, the sage, the teacher and the parrhesist owes much to Weber's conceptual separation of the prophet from the magician, the priest, the lawgiver and the teacher of ethics (Weber 1978a:439 - 446)"].

Parrhesis is the beginning or primal cause for conversation whether painted, spoken, or written. This action presents a movement of and toward an open heart. Parrhesis seeks ears and voices to support the kinesis and subsequent discourse. The variability of " $X$ " presents the unknown or uncontrollable that (should) spark the communication and open hearts. Indeed Kennan's preference thus would fall under the "reflexive historical sociologists" temperament as "...a choice between the philosophical life and the search for understanding..." in the context of Szakolczai's argument on parrhesia [42, p. 92, also 97, 186, 249], [41, pp. $179-186,197,253,255,256]$, [44, p. 31]. Kennan, as contemplative parrhesist, [44, pp. 19 - 23] encourages understanding to promote the best rather than a particular truth. We concur, but this poses the critical question whether and to what extent hearts can be melted during critical political moments such as pacted transitions, colour revolutions, and peace negotiations. Some post-socialist states seem to have made this leap, such as in Czechoslovakia's Velvet Revolution and Divorce, while contemporary developments in Bosnia and Herzegovina, Serbia, Macedonia, Montenegro, Kosovo, and Ukraine suggest a rejection of parrhesis, conversation, and the call to think with your heart.

\section{Thinking with Your Heart}

Voegelin commenting on The Gorgias [49], [3, pp. 28 - 29] seems only partly correct concerning communication (and from our perspective parrhesis). He is correct that at the level of the heart people "reason" differently, but Voegelin's interpretation of that element or "pathos" seems only partially valid. He correctly states that in spite of Socrates' deep "pathos," Socrates cannot lead Callicles to speak with his heart. So too, Voegelin acknowledges that Callicles' resistance does not excuse him from Socrates. He asks:

....Here, in the Gorgias, the situation is revealed in which the conception of a metamorphosis of Eros originates. The issue at stake is that of communication and intelligibility in a decadent society. Are the existential differences between Socrates and 
Callicles so profound that the bridge of a common humanity between them has broken down?

Voegelin answers that Callicles as the spoiler must either open his heart or live in the world of nothing, "Eros." Thus, Voegelin's "pathos" is a passive experience for humans:

... Pathos is what men have in common, however variable it may be in its aspects and intensities. Pathos designates a passive experience, not an action; it is what happens to man, what he suffers, what befalls him fatefully and what touches him in his existential core - as for instance the experience of Eros (481c-d). In their exposure to pathos all men are equal, though they may differ widely in the manner in which they come to grips with it and build the experience into their lives. $<\ldots>$ The community of pathos is the basis of communication. Behind the hardened, intellectually supported attitudes which separate men, lie the pathemata which bind them together. However false and grotesque the intellectual position may be, the pathos at the core has the truth of an immediate experience. If one can penetrate to this core and reawaken in a man the awareness of his conditio humana, communication in the existential sense becomes possible [49, p. 83].

Pathos and pathemata are experiences and sufferings which happen to us: humans are passive in these events, but these events offer common ground beyond "hardened, intellectually supported attitudes which separate men..." In this sense it seems some barrier blocks the core of Callicles' heart. What is that "one" or "... if one can penetrate..." which would engender movement? Could that "one" or pathos be the one-and-the-same spirit which leads one to ascend to a higher epistemological level as in Plato's cave metaphor [37, Book VII, 514a-521d] or Gorbachev's glasnost? Are these instances of the spiritually awakened person? And, must individuals initially will to place themselves into spiritual reflection, to undergo parrhesis, and ultimately engage in communication, i.e. return into the cave?

It seems, Voegelin does not attribute appropriate strength to this Foucauldian will/pleasure of a spiritual awakening which allows conditio humana communication to follow. This awakening process often seems a painful (spiritual and physical) journey for societies in transition as in Poland's pacted transition and shock therapy. Yet, the people and leaders in Poland accepted submission to "one [who] can penetrate to the core," allowing the painful process towards the "gnosis" of "X." Simultaneously active and passive, this movement to parrhesis, illuminates the vital spark in Kennan's "X" variable.

Indeed, for Voegelin not only is the process passive, but conversation is secondary in as much associeties seem to lie in the world of silence and darkness prior to conversation. But what is that movement which ends the darkness, silence, and immotion, if not the very spark of the will to cross-cut, i.e. scission or "con-soci-ation" or conversation, within one and thus between two. It is this aspect of conversation as a form of multiplication and motion that is found in the art paintings on the walls of caves [45]. It is this aspect that emerges into the grand polyphony of multiple human voices in Plato's dialogues. Gorbachev also submitted, awakening such will, thawing frozen hearts, and thus engendering pathos. Perhaps then the divinely inspired core where pathos lies and conversation is sparked, also is a magnetic monadic level that contains conditio humana. At this magnetic core, this monadic level of potential pathos and parrhesis, remains a question: why Kennan and Gorbachev, and not Callicles? The process from immobility into Plato's kinesis, must begin within whereby one "con-verts" the heart, and opens up the passage to pathos. What we suggest is that awakening the condito humana and thus the pathos in the core of human existence starts first with the will against the will and the assent to submit, to enter parrhesis.

This assent to submit, both active and passive, to parrhesis is that " $X$ " variable. But how does one translate this pathos-filled conversation into hierarchies of international relations (IR) and domestic politics when the moments of parrhesis are limited? Callicles' types prefer power and rhetoric to justice and community. Voegelin seems to argue that such conversation becomes an almost impossible task in the world of political religions or modern gnosticism [48]. His conclusion 
while pessimistic, seems realized in today's failure of elite led democratic transitions and permanent ethnoreligious conflict. Leaderships in Bosnia and Herzegovina, Kosovo, and Ukraine seem to possess hardened hearts resistant to reconciliation. As with Callicles, some people simply do not desire conversation. They reject Kennan's parrhesis preferring rhetorical conclusions based upon unrealities or a dream world [20]. Further, some leaders reject pathos and morality, employing their superior skills and power to maintain control. Macedonia's Colorful Revolution simultaneously illustrates and responds to such concerns. What is to be done? Kennan's "X" variable suggests that individuals must find their "pathos" to minimize the differences and highlight the conditio humana. " $\mathrm{X}$ " lies in the difficult journey towards the pathos which opens the conversation.

\section{Contemporary Political Contemplation and Conversation}

To understand the transitory moments in which the human condition now exists - the post-cold war era of complex conflicts, informal violence, non-state actors, multiplying gods and no gods - one requires a bird's eye view of the world. Such perspective does not necessitate the knowledge of multiple languages to understand, and perhaps even share, the "Other" view point. One only needs to possess the courage to listen and open the heart to different views. Many forces threaten contemporary transitory regions: environmental crisis, refugee flows, cyberterrorism, technological depersonalization, and human commodification. We are concerned, however, with the hushing down (or minimally Foucault's controlling) of dialogue and conversation. In the gnostic world, citizens and particularly leaders no longer engage in the truth-telling discourse of Plato's dialogues. This is most evident in totalitarian systems, but so too among dictatorships and elite controlled polyarchies. In the latter, the system is by the people, but not for the people; polyarchies in postsocialist regions variously frustrate, confuse, and manipulate the powerless, dividing and freezing societies in transition.

Some societies risk implosion from frozen conflicts or suspended democratisation. Societies emerging from authoritarianism have witnessed self-interested elites who advance their own power, too often through violent exclusive nationalism, rather than the civic trust and inclusive norms necessary to consolidate democracy. In some instances, well established conflict management mechanisms offer a bridge away from violence, but elites remain resolute regarding their particular nationalism at the expense of a common "best" future. In the former Yugoslavia Macedonia, Kosovo, and Bosnia and Herzegovina are trapped in such transition. Elsewhere too in post-Soviet Europe (Georgia, North Ossetia, Abkhazia, Ukraine, Crimea, and Moldova) efforts to democratise face a roller-coaster ride of institutional decline and social polarisation. Indeed, even among states such as Hungary which have entered NATO and the EU, worrisome intolerance ferments. Elites and masses prefer a buffet style democracy in which they can select their own combination of rights and freedoms, rather than compromising and sharing on the offerings of governance. These situations advantage elites who do not engage in parrhesis. They lack pathos for conditio humana, and instead as tricksters monopolize conversation [23], [24], [25], [26], [27], [29], [31] locking individuals into liminal states in which souls are corrupted and constrained. The result places democratic values and institutions under pressure from schismatic forces which reject norms of openness and inclusion, and threaten to stall transition or shred democracy.

Accordingly, we suggest the wisdom of Kennan's spiritual reflections for regions of suspended democratisation. Kennan served as US Ambassador to Yugoslavia from 1961 - 1963, and worked to maintain Yugoslavia's neutrality in the Cold War context. At the end of his ambassadorship, Kennan travelled to Skopje to donate blood to Macedonian earthquake victims. Such an act was consistent with his spirituality which called for doing the best and focusing upon human survival, progress, and dialogue. Such an act shared the human condition. Thus, the symbolism of his $\mathrm{X}$ and the possibilities of his parrhesis now resonate with the situation in the region in which much of existence seems to be an unknown variable given the contending absolute ethnic and religious truths of leaders. X conveys a lack of identity, or at the minimum refusal to 
identify, separate and/or prescribe. This confusion of identity lost can be resolved through inclusion in a democratic polity which refuses to separate and/or prescribe identities into contending ethnoreligious nationalisms that impede a common humanity and therefore future. Many talented individuals already have emigrated from the region; other individuals inclined to conversation are marginalized. What would Kennan write in an X Article to transitional societies emerging from authoritarianism or conflict? What would Kennan say about the post-Dayton situation in Bosnia and Herzegovina which for centuries was known for its ecumenical tolerance, willingness to embrace difference as normal, and Olympic cosmopolitanism? How can this society and other post-socialist societies move from externally supported and engineered transitions to an indigenous parrhesis? How might the European Union's Special Representatives finally leave Bosnia and Herzegovina, Kosovo, and Georgia? And is it possible for Ukraine to avoid a renewed hot war and move beyond a frozen conflict?

A culture of dialogue seems an essential prerequisite for divided societies and post-socialist, post-conflict states in constructing a durable democratic outcome. For example, since the conflict and celebrated Dayton Peace, Bosnia and Herzegovina exists in a trapped liminal state of mimetic violence, contending gnoses, and apocalyptic histories (on liminality see [15], [42], [46], [47], on Yugoslavian crisis see [38]). The tri-partite leadership pursues a spiritual deconstruction which denies the shared Abrahamic monotheism. Society(ies) and the state reel. A comparable situation exists in Kosovo. The frozen conflict in the Ukraine appears worse, threatening to disintegrate into renewed violence rather than engage in meaningful dialogue. As during the Cold War, "artificial created unrealities are more important than realities" [39, p. 215]. Each ethnoreligious leadership claims "the Beyond" for his/her nation and levels the gnostic claim: I will destroy the idols and replace them with the true God. As during Soviet purges and American McCarthyism, the polity and land will be cleansed of anyone who is an infidel, or appears to be an infidel, or even assumes an "other" identity. The outcome of contending leaderships within one state, each engaging in such gnostic action and reaction, leads not to dialogue, but rather a void, or worse, chaos in which some people perceive elites as unresponsive, irresponsible, and corrupt, while others accept leaders as God-like re-presentations. In the absence of critical reflection, and therefore pathos, the leadership fails to contemplate their shared human sufferings and experiences.

Kennan's warning for such societies possibly would parallel his warning at the start of the never declared Vietnam War, "we cannot conclude that everything we want automatically reflects the purpose of God" [39, p. 202]. So too, Kennan stated “... real events had to be denied, false ones invented, or true facts distorted beyond recognition in order to produce a version that was compatible with the party's neurotic vision of the environment in which it lived and of its own reaction to that environment" [39, p. 207]. The termination of the inner quest for truth leads to a quest to impose truth upon others, which then degenerates to violence and chaos. Such is the situation in lands beset by significant ethno cum linguistic conflicts. These contested regions witness the inability to tolerate the polyphony of other point of views. Ethno-nationalism now offers an alternative to democracy in Bosnia and Herzegovina, Kosovo, Moldova, Georgia, and Ukraine where resolute leaders seek to impose their own truths and build local empires of ethnic-religious identity. They ignore their shared experiences and sufferings under other empires and ideologies, and focus upon divisive, hardened rhetoric and attitudes. This Calliclian response to the possibility of parrhesis and discourse not only rejects the opportunity of movement to the best, but at times justifies interference from external gnostic empires.

Alternatively, a responsive civilizing leadership will consistently challenge itself to consider values and processes that allow for the ongoing revelation of truth, appreciating that it cannot be known in whole and should not be assumed to or imposed as such. A genuine democratic leadership is contemplative, and not dismissive. Civilized leadership embraces a parrhesis which commits its quest to the common good. In the case of societies and states caught in suspended democratisation processes, such parrhesis necessitates each member abandon egocentrism and engage in a selfless effort to clarify unreality and reality. Leaders must recall, appreciate, and emphasize the shared 
human condition. All their people seek jobs, peace, security, and well-being. Their leaders must balance the multiple realities, moving to the best, and rejecting temptations to devolve into the violence of contending truths.

During the Cold War, the gnostic conclusions of the US and the USSR led each superpower on messianic crusades to create utopian empires. Such crusades displaced Kennan's preference for contemplative leadership which offers an example of searching for the best within one's reality. The mimetic, crusading violence of empire-building justified and required force, domination, and the imposition of the "true" culture. Indeed, remnants of these gnostic campaigns still impede transition in post-socialist states. Consider the 2016 coup attempt in Montenegro, tripartite leadership dispute over genocide in Bosnia and Herzegovina, ongoing conflict in Ukraine, and recent efforts at walling in Serb regions of Kosovo. In each case gnostic voices over power genuine democratic leadership that seeks in a pluralist fashion simultaneously to support other peoples' world-views and find their own best. These Gnostics pursue winning and empire, locking people into the simplistic unreality of frozen conflict without contemplation of how to transition or progress (see on Dayton [4], [5], [6], [7], [8], [9], [10], [11], [33], [34], and contra arguments [19], [32]). Post-socialist leaderships must transcend and become open to the parrhesis of fluid and multiple identities because the assertion or demand of singular and fixed identity is an unreal truth. If Calliclian leaders continue to resist such reflection and movement, then Socratic voices within European and local civil societies must initiate the discourse, criticizing the rhetoric of the sophists, and advocating for parrhesis and heartfelt pathos for the human condition.

\section{Conclusion}

To claim to know a specific solution to the stalled transitions and frozen conflicts denies the necessity of indigenous contemplation, thrusting us into sophistry and ideational empire-building. Yet, our analysis suggests that the way forward is for leadership to sincerely strive to do what is best. Those who refuse and claim a singular truth are messianic elites bent on empire building who must be challenged by diverse voices: Socrates, Voegelin, Kennan, the European Union, and local civil society. The way forward for conflictual world-views is through parrhesis, a culture of dialogue, and discourse. Global actors, including the US and EU must encourage and model civilizing leadership, with a balance between involvement and detachment. Notably, Foucault criticized France for its failure to sufficiently support Solidarity and its movement of collective will in Poland. The international community should encourage reflection and communication, but leave the essential conversation to the local people. We do not forget that European powers waged the world wars and Cold War. Far from being idealists and glorifying the West, we emphasise the delicate social and institutional transitions which must occur to transcend authoritarianism and attain freedom.

Individuals and societies must will to uncover and spark contemplation, allowing parrhesis and conversations. The renewal of communication among open hearts invites an understanding of differences and entrance into common ground among people who have shared past experiences. Currently people experience similar sufferings, but in segregation and isolation. They suffer under unhealed scars of war, the broken promise of transition, and the festering wounds of unemployment and corruption. Opening one's heart to listen to other hearts created channels for civilizing movement in other difficult situations such as Northern Ireland and South Africa. The movement can engender common cause to call forth and support leaders who challenge the tricksters' mentality which relishes in power and permanent liminality. As in the case of Poland's Solidarity, leadership that a priori accepts different world-views as normality rather than threat is an asset.

Recall in this regard, that Solidarity arose from civil society. Elsewhere, civil society movements can press leaders. Bosnia and Herzegovina's Dosta (in English, "Enough") often offers a nourishing environment for conversations of the heart. These conversations can be asymmetrical; Dosta initially opens the discourse to present a truth of what is felt, and invite a reassessment of the 
truth. Dosta and other movements and groups reflect and communicate, inviting conversation with leaders. Likewise, local exercises akin to Macedonia's truth and reconciliation commissions have provided the safe (perhaps sacred) space for people to offer and hear truths, share common experiences, and move beyond unrealities. So too, the process of conversion of the heart must spark democratic leaders to reflect upon their shared conditio humana, setting aside "attitudes which separate." Post-socialist societies, particularly regions which have experienced violence, lack a guaranteed future. Elitism sometimes nullifies the conversations and conversion of the heart of peace treaties, colour revolutions and pacted transitions. Power politics fuelled with the rhetorical competition between gnostic truths then seem doomed to trap people into a stalled transition or even cyclical violence. By contrast, acceptance of the uncertainty of $\mathrm{X}$ accompanied with a willingness to listen, a commitment to compassion (that is com-pathos), and a movement to heart-felt discourse open the opportunity to promote Kennan's best outcome. Reflection and discourse, however, require courage to embrace uncertainty. Decades passed before Willy Brandt's heart-felt, silent, spontaneous genuflection at the Warsaw Ghetto. Reflection, acceptance of difference, and discourse requires commitment and persistence. Kennan, understanding the uncertainty of X, probably would counsel the former Soviet and East European regions he knew so well to consider Winston Churchill's dictum: "courage is what it takes to stand up and speak; courage is also what it takes to sit down and listen."

\section{References}

1. Bakhtin, M. M. The Dialogic Imagination: Four Essays, Austin: University of Texas Press, 1981.

2. Bateson, G. Naven, Stanford: CA: Stanford University Press, 1958.

3. Bateson, G. Steps to an Ecology of Mind, New York: Ballantine: 1972.

4. Bose, S. Bosnia after Dayton: Nationalist Partition and International Intervention, London: Hurst, 2002.

5. Bose, S. Contested Lands: Israel-Palestine, Kashmir, Bosnia, Cyprus, and Sri Lanka, Cambridge, Mass.: Harvard University Press, 2007.

6. Bunce, V. Should Transitologists be Grounded? Slavic Review, 1995, pp. 111-127.

7. Bunce, V. Subversive Institutions: The Design and Destruction of Socialism and the State, Cambridge: Cambridge University Press, 1999.

8. Bunce, V. Rethinking Recent Democratization: Lessons from the Postcommunist Experience, World Politics, 2003, pp. 167-92.

9. Burg, S.L. and Shoup, P. The War in Bosnia-Herzegovina: Ethnic Conflict and International Intervention, London: M.E. Sharpe, 1999.

10. Crnobrnja, M. The Yugoslav Drama, London: Tauris, 1996.

11. Dahl, R. A. Polyarchy: Participation and Opposition, New Haven: Yale University Press, 1971.

12. Foucault, M. Discipline and Punish: The Birth of the Prison, New York: Vintage Books, 1979.

13. Foucault, M. The History of Sexuality, London: Allen Lane, 1989.

14. Foucault, M. Fearless Speech. Los Angeles: Semiotext(e), 2001.

15. Gennep, A. V. The Rites of Passage, Chicago: University of Chicago Press, 1960.

16. Girard, R. Violence and the Sacred, Baltimore: Johns Hopkins University Press, 1977.

17. Girard, R. To Double Business Bound: Essays on Literature, Mimesis, and Anthropology, London: Althone Press, 1978.

18. Girard, R. The Scapegoat, Baltimore: Johns Hopkins University Press, 1989.

19. Havel, V. The Power of the Powerless, in The Power of the Powerless, London: Hutchinson \& Co., 1985, pp. 23-96.

20. Hennigsen, M. The Dream World of Tyrants: The Teachings of Socrates' Students, Beitraege zur Politschen Wissenschaft, 2008, pp. 131-145.

21. Hennigsen, M. On the Ruins of Civilisations: The Regimes of Terror, in Revolutions: Finished and Unfinished, from Primal to Final, Newcastle: Cambridge Scholars, 2012, pp. 133-153. 
22. Homer. Homer: Odyssey, Clarendon: Oxford University Press, 1899.

23. Horvath A. and Thomassen, B. Mimetic Errors in Liminal Schismogenesis: On the Political Anthropology of the Trickster, International Political Anthropology, 2008: pp. 3-24.

24. Horvath, A. The Political Psychology of Trickster-Clown: An Analytical Experiment around Communism as a Myth, EUI Working Paper, 1997, pp. 1-30.

25. Horvath, A. The Trickster Motive in Renaissance Political Thought, Philosophia, 2007, pp. 95111.

26. Horvath, A. Mythology and the Trickster, in Democracy and Myth in Russia and Eastern Europe, London: Routledge, 2008.

27. Horvath, A. Pulcinella, or the Metaphysics of the Nulla, History of the Human Science 23 (2), 2010a, pp. 47-67.

28. Horvath, A. Modernism and Charisma, London: Palgrave, 2013.

29. Horvath, A. Tricking into the Position of the Outcast: A Case Study in the Emergence and Effects of Communist Power, Political Psychology, June, 1998, pp. 331-347.

30. Kennan, G. The Sources of Soviet Conduct, Foreign Affairs, 25:41947, pp. 566-582.

31. Keohane, K. Trickster's Metempsychosis in the Mythic age of Globalization: The Recurrence of the Leprechaun in Irish Political Culture, Cultural Politics, 2005, pp. 257-278.

32. Kymlicka, W. Multicultural citizenship: A Liberal Theory of Minority Rights, Oxford: Clarendon Press, 1995.

33. Lijphart, A. Consociation and Federation: Conceptual and Empirical Links, Canadian Journal of Political Science, 1979, pp. 495-515.

34. Linz, J.J. and Stepan, A. Problems of Democratic Transition and Consolidation: Southern Europe, South America, and Post-Communist Europe, Baltimore: Johns Hopkins University Press, 1996.

35. Norbert, E. The Civilizing Process: State Formation and Civilization, Oxford: Blackwell, 1982.

36. Norbert, E. Involvement and Detachment, Oxford: Blackwell, 1987.

37. Plato. Plato's Republic, Cambridge: Cambridge University Press, 1996.

38. Ramet, S. Whose Democracy? Nationalism, Religion and the Doctrine of Collective Rights in post-1989 Eastern Europe, Oxford: Rowman \& Littlefield, 1997.

39. Rossbach, S. Gnostic Wars: The Cold War in the Context of a History of Western Spirituality, Edinburgh: Edinburgh University Press, 1999.

40. Szakolczai, A. Identity Formation Mechanisms: A Conceptual and Geneological Analysis, EUI Working Papers, 1998.

41. Szakolczai, A. Max Weber and Michel Foucault: Parallel Life-works, New York: Routledge, $1998 b$.

42. Szakolczai, A. Reflexive Historical Sociology, London: Routledge, 2000.

43. Szakolczai, A. Image-magic in a Midsummer Night's Dream, History of the Human Sciences 20: 4, 2007, pp. 1-26.

44. Szakolczai, A. Comedy and the Public Sphere, New York: Routledge, 2013.

45. Szakolczai. A. Permanent (trickster) liminality: The Reasons of the Heart and of the Mind, ESF

Exploratory Workshop, Affectivity and Liminality: Conceptualising the Dynamics of Suspended

Transition, 2014,

https://cora.ucc.ie/bitstream/handle/10468/1281/AS PermanentSV2013.pdf?sequence $=4$

46. Turner, V. The Forest of Symbols: Aspects of Ndembu Ritual, Ithaca, NY: Cornell University Press, 1970.

47. Turner, V. Blazing the Trail: Waymarks in the Exploration of Symbols, Tucson: University of Arizona Press, 1992.

48. Voegelin, E. The New Science of Politics: An Introduction, Chicago: University of Chicago Press, 1952.

49. Voegelin, E. Order and History: Vol III Plato and Aristotle, Columbia, MO: University of Missouri Press, 2000. 